ing our understanding of the relationship between development and the complex dynamics of the lifesupport system of our planet; with generating new approaches, new ideas, and new ways of knowing and understanding; with establishing dialogue, coordination, and cooperation, between scholars and practitioners of development and scholars and practitioners of Biosphere preservation. The Council will advise the members of ISEE on the topics, issues, concerns, and problems, that should be addressed by new educational programmes. It will also advise on target audiences for such educational programmes.

To date we have seated six Councillors and hope to seat some more by early 1984. The six (in alphabetical order of family names) are:

Reid A. Bryson (USA), Professor of Meteorology, Director of the Institute for Environmental Studies, University of Wisconsin-Madison, Wisconsin

Lynton Keith Caldwell (USA), Arthur F. Bentley Professor of Political Science, Indiana University, Bloomington, Indiana

Mohamed Kassas (Egypt), Ecologist, President of IUCN, Professor of Botany, University of Cairo

Nicholas Polunin (Switzerland), Biospheral Environmentalist, President of the Foundation for Environmental Conservation, Geneva

M.S. Swaminathan (India), Geneticist, Director-General, International Rice Research Institute, Manila, Philippines

John R. Vallentyne (Canada), Limnologist, Canada Centre for Inland Waters, Burlington, Ontario
2. THE INTERNATIONAL SOCIETY FOR ENVIRONMENTAL EDUCATION: The Society will serve as an instructional network, gathering information, organizing it into educational materials and programmes, and disseminating the results to a wide variety of target audiences throughout the world.

Thus, the Council and ISEE are widely complementary; the Council serves ISEE by providing content, purpose, and direction, while ISEE serves the Council by 'putting the message over' globally.

The first general meeting of WCB/ISEE is scheduled for 23-29 February 1984 in New Delhi and Udaipur, India. This meeting is designed to be small, not more than fifty participants, and productive. The first three days' sessions will be held in New Delhi and will be devoted to organizational matters, deliberations of the Council, and formal presentations of invited papers and reports. After a day set aside for travel and more leisurely deliberations, the last three days will be spent in a more informal setting in Udaipur, where we can roll up our sleeves and get some work done on setting goals and initiating our first educational projects. If you are suitably qualified and interested in being involved with $W C B / I S E E$ and/or participating in the first meeting, please contact the undersigned.

CRAIG B. DAvIS, Secretary-General of WCB/ISEE World Council For The Biosphere 141 Bessey Hall

Iowa State University

Ames

Iowa 50011, USA.

\title{
International Aspects of Proposed Amendments to the Alaska National Interest Lands Conservation Act
}

The Alaska National Interest Lands Conservation Act (ANILCA) was signed into law by President Carter on 2 December 1980. The legislation apportioned $41,684,000$ ha of land for management under the following conservation regimes: national parks, national monuments, national preserves, wildlife refuges, wild and scenic rivers, and national forests. Passage of the legislation was marked by extensive political wrangling among pressure-groups, governmental officials, and politicians. The debate was initiated in section 17(d) (2) of the 1971 Alaska Native Claims Settlement Act, which called for setting aside over $32,000,000$ ha of land for study as potential conservation reserves. Conservation arrangements codified in ANILCA in the end reflect compromise and accommodation among all interests that participated in the lengthy legislative debate (Wayburn, 1983 - cf. also Cahn, 1982; Fenge, 1982).

The Alaskan conservation system is, however, threatened by proposed amendments to ANILCA forwarded by Senator Stevens (bill S49 in the United States Senate) and Representative Young (bill HR1493 in the United States House of Representatives). These amendments would downgrade nearly $4,800,000$ ha of the land in national parks and monuments to national preserves, in order to increase the amount of land available for sport hunting (Wayburn, 1983). Eight of the ten national parks in Alaska would be affected by the proposed amendments (Table I).

While the proposed amendment of ANILCA is clearly a matter for Americans to resolve, the debate has an international flavour, for some of the national parks are of widely-recognized international importance. For ex-
TABLE I

The Impact of Bills S49 and HR1493

on National Parks established by ANILCA.

\begin{tabular}{lrrr}
\hline National Park & $\begin{array}{c}\text { Total area } \\
\text { (ha) }\end{array}$ & $\begin{array}{c}\text { Area altered } \\
\text { to Preserves } \\
\text { by S49 and } \\
\text { HR1493 }\end{array}$ & $\begin{array}{c}\text { Percentage } \\
\text { Reduction }\end{array}$ \\
\hline Aniakchak & 55,752 & 35,552 & 64 \\
Denali & 980,104 & 616,504 & 63 \\
Gates of the Arctic & $2,849,000$ & $2,059,996$ & 72 \\
Glacier Bay & 211,292 & 86,456 & 41 \\
Katmai & 418,948 & 418,948 & 100 \\
Kenai Fjords & 229,068 & 229,068 & 100 \\
Lake Clark & 985,356 & 414,100 & 42 \\
Wrangell-Mt St Elias & $3,291,388$ & 938,088 & 29 \\
\cline { 2 - 3 } & $9,020,908$ & $4,798,712$ & 48 \\
\hline
\end{tabular}

ample, the Wrangell-Mt St Elias National Park is, with Kluane National Park in Yukon, Canada, designated a World Heritage Site under the World Heritage Convention. These conservation reserves were jointly nominated for World Heritage status by the two national governments in 1979.

The letter of application to the World Heritage Committee, signed by the Canadian Minister of Indian and Northern Affairs and the American Secretary of the Interior, notes that the conservation reserves together are: 
....a joint resource which remains intact as an unbroken natural system, despite the long presence of political boundaries.'

Within the accompanying documentation both Governments note:

'Over 14,000 Dall's Sheep [Ovis canadensis s.1.], the single largest group in the world, are found on lands encompassed by the nomination.

Proposed amendments to ANILCA would open a stretch of $113 \mathrm{~km}$ of land, encompassing an area of more than 650,000 ha along the Canada-USA border, to sport hunting. Therefore a significant portion of the World Heritage Site in Alaska would be subject to sport hunting.

Dall's Sheep migrate back and forth across the Alaska-Yukon boundary, hence the legitimate Canadian concern about proposed revision of ANILCA. This situation was not contemplated in the 1979 nominationnor, presumably, was it envisaged by those who adjudicated the application. However, removing much of the land within Wrangell-Mt St Elias National Park from management under National Parks legislation raises the question of international obligations assumed by states when administering World Heritage Sites and, in this case, a specific obligation to the Government of Canada as a joint nominee of the site.
It is to be hoped that the international recognition and status which has been accorded the Site will restrain efforts to disestablish large portions of Wrangell-Mt St Elias National Park. Should the proposed amendment be passed, we may wonder how many other World Heritage Sites could suffer a similar fate to this first jointlynominated one!

\section{REFERENCES}

Cahn, R. (1982). The Fight to Save Wild Alaska. National Audubon Society, Washington, DC, USA: 32 pp., illustr.

FENGE, T. (1982). Towards comprehensive conservation of environmentally significant areas in the Northwest Territories of Canada. Environmental Conservation, 9(4), pp. 305-13, map.

WAYBURN, E. (1983). Hunters take aim at Alaska's National Parks: S49 and HR1493. Sierra, 68(3), pp. 16-9.

Terry Fenge, Director of Policy Studies Canadian Arctic Resources Committee 46 Elgin Street, Room 11

Ottawa

Ontario K1P $5 K 6$

Canada.

\section{Australian High-court Decision Ensures Preservation of the South-West Tasmanian Wilderness}

On 1 July 1983 the High Court of Australia handed down a decision which had the effect of causing construction work on a hydroelectric dam on the lower Gordon and Franklin Rivers in South-West Tasmania to be abandoned. The action by the High Court appears to be the final move to preserve the South-West Wilderness area of Tasmania, after a public debate which has been long-drawn-out, sometimes tangential, and widely acrimonious. ${ }^{*}$ The nature of the High Court case also appears to provide substantial legal precedent for greater involvement of the Federal Government in future environmental conservation issues in Australia.

By a 4 to 3 majority the Court upheld the constitutional validity of the World Heritage Properties Conservation Act, passed by the Australian Federal Parliament in May 1983. This Act was the means chosen by the Australian Labour Party government, led by Mr Robert Hawke, to meet the commitment to halt the Gordon-Franklin project which it had made during the election campaign three months earlier, and in which it gained office. The Act gave the Federal Government powers to prevent actions that would damage any properties in Australia which have been included on the World Heritage List. The nomination of substantial parts of the wilderness area of South-West Tasmania for inclusion on the World Heritage List was accepted in December 1982. The Federal Government argues that following the listing it was obliged, as a result of its adherence to the World Heritage Convention, to take action to protect listed areas.

The intent of the World Heritage Properties Conservation Act is to require that any action that damages

\footnotetext{
* See Dr Andrew K. Dragun's account of 'Hydroelectric Development and Wilderness Conflict in South-West Tasmania', published in our latest issue (Environmental Conservation, 10(3), pp. 197-204, 6 figs, Autumn 1983), and other items in recent issues.-Ed.
}

a property, the protection or conservation of which is a matter of international obligation on the part of Australia - whether by reason of the World Heritage Convention or otherwise - may only be undertaken with the consent of the Federal Government. This requirement is to apply to all Australian persons and organizations in Australia, including state governments and their agents. The body responsible for building the lower Gordon dam, the Hydro-Electric Commission of Tasmania, is a whollyowned agency of the Tasmanian State Government.

Prior to passage to the Act, the Federal Government sought to halt construction of the dam by means of regulations made under an existing piece of legislation, the National Parks and Wildlife Conservation Act. It went to the High Court for an injunction that the Tasmanian State Goverment comply with these regulations, while Tasmania made a counter-claim that the regulations were constitutionally invalid. Hearing of the matter did not start before passage of the new Act, and it was then agreed by discussion between the parties that the case should address the constitutional validity of the new Act. In essence Tasmania contended that the Act was unconstitutional and a violation of state rights, which traditionally have included matters pertaining to the environment.

The case was heard by the Full Bench of seven judges of the High Court during May and June 1983. The parties were in substantial dispute over environmental and economic implications of the hydroelectric scheme, and submitted considerable evidenciary material in support of their respective positions. However, the Court found that these disputed allegations did not affect the validity or otherwise of the Act, and made no judicial determination on them. In essence the High Court found that the Federal Government does have the power to enact legislation which might override state legislation on such matters as the environment, and that federal legislation is in line with international agreements and treaties which 